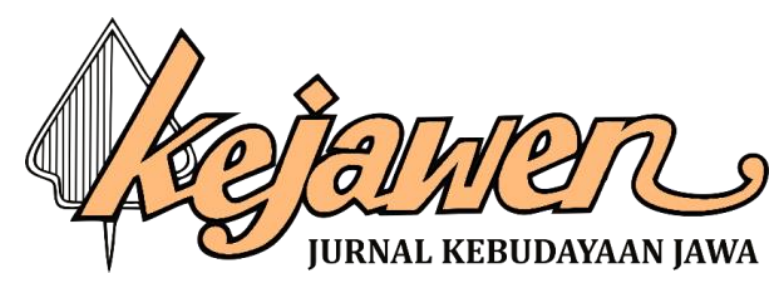

\title{
RELEVENSI STANDAR KECANTIKAN DEWI SINTA DALAM SERAT RAMAWIJAYA DENGAN KESETIAAN SEORANG ISTRI
}

\author{
Nur Izzah Amalia, Respati Retno Utami \\ Universitas Negeri Surabaya \\ nurizzah.18011@mhs.unesa.ac.id, respatiutami@unesa.ac.id
}

\begin{abstract}
Abstrak
Artikel yang berjudul Relevansi Standar Kecantikan Dewi Sinta dalam Serat Ramawijaya dengan Kesetiaan Seorang Istri memiliki tujuan untuk mengulas perihal bagaimana penggambaran tokoh Dewi Sinta dalam Serat Ramawijaya, serta bagaimana relevansi standar kecantikan Dewi Sinta dalam Serat Ramawijaya dengan kesetiaan istri. Penelitian ini menggunakan metode penelitian kualitatif karena dalam penelitian ini akan mengumpulkan data langsung dengan cara mengutip poin penting yang mendasari pembahasan. Pendekatan yang digunakan disesuaikan dengan variabel penelitian, yakni pendekatan deskriptif. Teknik yang digunakan untuk mengumpulkan data dalam penelitian ini yakni menggunakan dua teknik, yaitu teori filologi dan metode studi pustaka. Dalam mengupas pembahasan yang ada dalam penelitian ini, juga menggunakan teori feminsime. Karena kajian feminisme mengulas permasalahan yang dialami oleh perempuan dalam segala lini kehidupannya. Hasil dari penelitian ini memunculkan citra fisik perempuan yang digambarkan melalui tokoh Dewi Sinta yang memiliki paras atau fisik yang cantik, setia, dan kepatuhan akan ketentuan Tuhan. Relevansinya yakni merepresentasikan perempuan sebagai istri memiliki paras cantik adalah suatu tantangan, harus menjadi perempuan yang patuh, dan sulit mengembangkan potensi dirinya.
\end{abstract}

Kata kunci: standar kecantikan, Dewi Sinta, kesetiaan istri

\section{RELEVANCY OF DEWI SINTA'S BEAUTY STANDART IN RAMAWIJAYA SCRIPT WITH A WIFE'S LOYALTY}

\begin{abstract}
Article with the title Relevancy of Dewi Sinta's Beauty Standart in Ramawijaya Script with a Wife's Loyalty aims to review how the depiction of Dewi Sinta in Serat Ramawijaya, as well as how the relevance of Dewi Sinta's standard of beauty in Serat Ramawijaya and her wife's loyalty. This study uses a qualitative research method because in this study it will collect direct data by citing important points that underlie the discussion. The approach used is adjusted to the research variables, namely the descriptive approach. The technique used to collect data in this study is to use two. First, using philological theory and literature study method. In discussing the existing discussion in this study, feminism theory is also used. Because the study of feminism examines the problems experienced by women in all lines of life. The results of this study bring out the physical image of women depicted through the figure of Dewi Sinta who has a beautiful, loyal, and obedient appearance to God's provisions. The relevance of representing women as wives having a beautiful face is a challenge, must be obedient women, and it is difficult to develop their potential.
\end{abstract}

Keywords: Beauty standart, Dewi Sinta, Wife's loyalty 


\section{PENDAHULUAN}

Cantik jika ditafsirkan berdasarkan bahasanya, merupakan bentuk dari kata sifat yang menggambarkan suatu keindahan yang dimiliki sesuatu baik itu manusia, alam, maupun benda. Jika sudah diberi imbuhan konfiks ke-an dalam kata "cantik" menjadi "kecantikan" maka akan berubah menjadi sesuatu yang memiliki ciri atau sifat tertentu yang membentuknya. Berkaitan dengan hal tersebut, makna cantik oleh kebanyakan orang di kehidupan sosial ini yang masih terpenjara pikirannya oleh budaya patriarki, menumbuhkan suatu patokan atau standar untuk mendefinisikan seperti apa wujud yang dikatakan cantik itu sendiri. Kecantikan bersifat pelbagai. Kepelbagaian ini bermaksud kecantikan tidak hanya pada rupa paras tetapi juga kecantikan warna kulit, tubuh, rambut dan sebagainya (Wirasari, 2016 dalam Zahid, 2018:14). Tak cukup dari fisik saja namun juga dengan kepribadiannya yang turut diatur oleh kondisi sosial masyarakat. Dianggap menjadi perempuan yang baik sesuai dengan standar masyarakat yakni mereka yang memiliki sifat lemah lembut, keibuan, halus tutur katanya, penuh kasih dan sayang perilakunya, mudah menangis dan tersinggung adalah suatu kewajaran yang dilambangkan sebagai sifat wajib perempuan, yang mana perempuan diminta untuk berada pada statement tersebut guna mewujudkan serta melanggengkan wujud dari watak feminin buatan masyarakat sendiri. Namun, pada kejadiannya dalam serat Serat Ramawijaya, Dewi Sinta pun pernah hendak ditinggalkan oleh Prabu Kencana ketika ia secara fisik sedang kusam, tidak cantik menurutnya, kurus, dan sebagainya yang disebut sebagai beauoir narsisme yang menguras waktu produktif perempuan hanya untuk pemenuhan kesempurnaan penampilan (Tong, 1998:270-271 dalam Royyan Julian, 2016:57).

Standar kecantikan Dewi Sinta dalam Serat Ramawijaya dalam penelitian ini dikaitkan dengan kesetiaan istri. Berdasarkan bahan penelitian dari Serat Ramawijaya, unsur kesetiaan istri terhadap suami digambarkan oleh Dewi Sinta kepada Ramawijaya. Dalam serat tersebut, Dewi Sinta digambarkan menjadi perempuan Jawa yang cantik, sebagaimana standar kecantikan yang diciptakan sendiri oleh masyarakat. Cantik parasnya, tinggi semampai, indah rambutnya, dan kuning mulus kulitnya. Namun, sekalipun ia adalah perempuan yang cantik dan sudah memiliki suami, Dewi Sinta tetap saja ada yang menggoda, yakni Rahwana. Maka bentuk kesetiaan yang dilakukan oleh Dewi Sinta yakni rela membakar diri demi membuktikan kesucian dan kesetiaan Dewi Sinta terhadap Ramawijaya. Itu jika dalam naskah, sama halnya dengan yang terjadi direalita kehidupan. Keadaan ketika istri ingin membuktikan kesetiaannya memang bisa ditunjukkan dalam berbagai bentuk.

Penelitian mengenai kesetiaan istri yang digambarkan oleh Dewi Sinta sebelumnya pernah ada, dan diteliti oleh Dewa Putu Suandinani dari Universitas Muhammadiyah Purworejo dengan judul Kajian Nilai Pendidikan Tentang Kesetiaan Seorang Istri Terhadap Suami dalam Ramayana. Memang dalam penelitian tersebut berisi tentang kesetiaan istri terhadap suami dan bertepatan sama menggunakan cerita Ramayana sebagai medianya. Namun, tidak sepenuhnya sama. Dalam penelitian karya Suandiani cerita Ramayana yang dimaksud sebagai penggambaran saja, dan yang digunakan sebagai dasar untuk menegaskan dan menyajikan data-data mengenai kesetiaan istri yakni menggunakan dasar agama Hindu yang mana dikutip dari kitab ajaran agamanya. Selain itu, variabel lain yang digunakan pada penelitian tersebut mengkaji nilai-nilai pendidikan terutama perihal pernikahan Maka dari itu, ada beberapa pembahasan mengenai peraturan baik secara agama Hindu maupun dari negara mengenai peraturan sebelum melangsungkan pernikahan.. Sedangkan, yang dibahas dalam penelitian ini yakni variabelnya tentang standar kecantikan perempuan yang digambarkan oleh tokoh Dewi Sinta dalam Serat Ramawijaya yang dikaitkan dengan kesetiaan istri.

Serat Ramawijaya merupakan teks lama Jawa yang tepat dianalisis menggunakan teori filologi. Serat ini merupakan terbitan sastra lama, banyak aspek yang perlu dikupas karena mengandung beberapa nilai yang masih memiliki korelasi serta kepentingan di era modern saat ini.Peranan teori filologi dalam penelitian suatu kajian sastra lama merupakan salah satu cara untuk 
memeroleh pemaknaan dari sastra lama tersebut. Menguak apa yang ada dalam teks sastra yang dikaji berdasar dari apa yang sedang diamati, dirasakan serta dipikirkan oleh peneliti sebagai aktivitas kritik sastra yang bersifat analistis secara apresiatif dan kreatif. Karena ada baiknya pada saat mengupas suatu sastra lama adalah yang memiliki nilai serta implikasi untuk era tertentu terutama era pada saat teks naskah tersebut diteliti dan dipublikasikan. Menurut Bambang Purnomo (2016:15) sejauh mungkin memahami kebudayaan umat manusia, yang mana melalui karya sastra yang hidup atau pernah hidup di tengah pada pendukung karya tersebut. Pemahaman fungsi naskah dan teks dapat dilakukan dengan cara penelusuran terhadap persepsi masyarakat terhadap eksistensi masing-masing naskah itu dari jaman ke jaman. Seperti dalam penelitian ini yang menguak topik perihal standar kecantikan dan dikaitkan dengan bab kesetiaan istri, yang mana menggali data dan mengungkapkan nilai-nilai yang ada pada Serat Ramawijaya. Penetapan teks sastra lama Jawa sebagai objek penelitian adalah suatu hal yang tepat. Penggambaran terhadap apa yang ada dalam kandungan teks sastra lama Jawa merupakan kegiatan menjelaskan, menjernihkan, menguak masalah ataupun pengertian untuk memahami isinya.

Dalam mengupas pembahasan yang ada dalam penelitian ini, juga menggunakan teori feminsime. Karena kajian feminisme mengulas permasalahan yang dialami oleh perempuan dalam segala lini kehidupannya. Agar lebih fokus, kajian ini menggunakan teori feminisme. Teori feminisme memusatkan perhatiannya pada tiga hal; pertama, objek utama kajiannya adalah situasi dan pengalaman perempuan dalam masyarakat; kedua, membicarakan perempuan sebagai subjek utama dalam proses kajiannya; dan ketiga teori ini kritis dan aktif membela perempuan, berusaha menghasilkan dunia yang lebih baik untuk perempuan pada khususnya dan manusia pada umumnya (Rahman, 2010:58). Sesui dengan variabel penelitian ini yang mengupas perihal keterkaitan standar kecantikan yang digambarkan oleh Dewi Sinta dalam Serat Ramawijaya dengan kesetiaan istri.

Maka dari itu dalam penelitian ini akan diulas perihal bagaimana penggambaran tokoh Dewi Sinta dalam Serat Ramawijaya, serta bagaimana relevansi standar kecantikan Dewi Sinta dalam Serat Ramawijaya dengan kesetiaan istri. Manfaat dari penelitian ini agar mengetahui bagaimana penggambaran tokoh Dewi Sinta dalam Serat Ramawijaya. Lalu, untuk mengetahui bagaimana relevansi standar kecantikan Dewi Sinta dalam Serat Ramawijaya dengan kesetiaan istri.Tujuan dari penelitian ini adalah untuk mengembangkan ilmu pengetahuan terutama mengenai kajian feminisme. Menggunakan sastra lama sebagai objek penelitian untuk keberlangsungan naskah dan sastra Jawa di tengah era modern. Dengan adanya penelitian ini diharapkan dapat menjadi pengetahuan baru untuk pembaca dan masyarakat tentang perkembangan ilmu pengetahuan, yang mana kajian feminisme di era modern ini dapat digunakan untuk mengkaji sastra lama Jawa.

\section{METODE}

Penelitian ini menggunakan metode penelitian kualitatif. Menurut Albi Anggito dan Johan Setiawan (2018:8) penelitian kualitatif adalah metode pengumpulan data pada suatu latar alamiah dengan maksud menafsirkan fenomena yang terjadi dimana peneliti adalah sebagai instrumen kunci. Sesuai dengan bahan penelitian yang diambil dari Serat Ramawijaya, peneliti menggunakan metode kualitatif karena dalam penelitian ini akan mengumpulkan data langsung dengan cara mengutip beberapa poin penting yang mendasari pembahasan, lalu dianalisis kemudian diinterpretasikan hasilnya. Dalam mengupas isi Serat Ramawijaya yang disesuaikan dengan variable penelitian, digunakan pendekatan deskriptif, yang mana menurut Iwan Hermawan (2019:15) bahwa pendekatan deskriptif berusaha menggambarkan apa yang ada di dalam data termasuk terhadap objek-objek apa saja yang ada di dalamnya. Jadi, dengan menggunakan pendekatan deskriptif akan lebih mudah untuk membuat deskripsi, gambaran atau lukisan secara sistematis serta hubungan antar fenomena yang diselidiki. Penelitian deskriptif merupakan jenis metode yang menggambarkan suatu objek dan subjek yang sedang diteliti tanpa adanya rekayasa. 
Termasuk mengenai hubungan tentang kegiatan, pandangan, sikap dan proses-proses yang berpengaruh dalam suatu fenomena yang terjadi yang ada dalam Serat Ramawijaya.

Ruang lingkup penelitian feminis kualitatif, memang masih terbilang rendah prosentasenya secara subjektif, banyak yang berasumsi bahwa penelitian feminis akan lebih subyektif terhadap pengalaman kaum perempuan yang mengalami diskriminasi. Banyak asumsi bahwa penyiksaan ataupun peristiwa traumatis perempuan yang mengalami diskriminasi dapat memunculkan subyektif. Meskipun demikian, feminisme memperhatikan hubungan dan interaksi kaum perempuan dengan orang lain untuk menyingkap kontrol laki-laki terhadap perempuan yang tersembunyi dalam keseharian. Dengan menggunakan metode kualitatif, peneliti bisa menunjukkan sejauh mana kelaki-lakian mendominasi perempuan.. Diharapkan dalam penelitian feminis kualitatif ini dapat memberikan kontribusi penting dalam memahami kondisi yang tengah terjadi.

Teknik yang digunakan untuk mengumpulkan data dalam penelitian ini yakni menggunakan dua. Yakni yang pertama menggunakan teori filologi, yang mana data primer berupa naskah diolah sebelum dianalisis. Tahapan peneliti menggunakan teori filologi untuk mengupas isi naskah Serat Ramawijaya yaitu mulai dari inventarisasi naskah, deskripsi naskah, transliterasi, kritik teks, dilanjut menerjemahkan naskah lalu mulai pada tahapan menganalisis apa yang terdapat dalam Serat Ramawijaya. Teknik yang kedua yakni menggunakan metode studi pustaka. Peneliti mengumpulkan data, sumber dan bahan penelitian dari berbagai literatur yang berkaitan dengan topik penelitian, guna mendukung juga membandingkan topik yang sedang diteliti, dengan penelitian lain yang sudah ada.

\section{HASIL DAN PEMBAHASAN}

Sumber data penelitian ini menggunakan data primer yang berasal dari naskah Serat Ramawijaya. Memiliki judul naskah lengkap Serat Cariyosipun Prabu Ramawijaya. Serat ini ditulis dan disalin oleh Ki Citrakusuma. Namun sayangnya tak tertera asal tempat naskah ini ditemukan atau ditulis. Meskipun demikian, bentuk fisik naskah ini disimpan dan dirawat dengan baik oleh pihak Museum Kambang Putih yang berlokasi di Jalan Kartini nomor 3, Kutorejo, Kecamatan Tuban, Kabupaten Tuban, Jawa Timur. Kondisi naskah saat itu masih bagus, namun pada bagian halaman belakang naskah kurang jelas penulisan aksaranya. Naskah ditulis di kertas tidak bergaris dengan ukuran beserta tebal naskah $22 \mathrm{~cm} \times 18 \mathrm{~cm} \times 1 \mathrm{~cm}$ serta ukuran teksnya $19 \mathrm{~cm}$ $\mathrm{x} 13,5 \mathrm{~cm}$. Jumlah total halaman sebanyak 174 dengan halaman dimulai pada lembar ke-105 dan hanya ditulis pada bagian recto, dengan nomor halaman menggunakan angka arab. Serat Ramawijaya ini berupa tembang dengan penulisan aksaranya menggunakan aksara Jawa carik dan berbahasa Jawa. Sayangnya, bagian ilumniasi serta kolofon tidak diketahui keberadaannya.

Pada pembahasan ini lebih difokuskan kepada tokoh Dewi Sinta yang sentral membahas tentang standar kecantikan yang direlevansikan dengan kesetiaan istri. Seorang perempuan digambarkan melalui citranya, yakni membagi dalam dua bagian besar yaitu citra diri dan citra sosial (Sugihastuti, 2000:68 dalam Maghfiroh, 2018:71). Citra diri terbagi menjadi dua yakni ada aspek fisik dan aspek psikis, sedangkan citra sosial terbangun dalam dua aspek yakni peran perempuan dalam keluarga dan peran dalam masyarakat. Dalam penelitian ini akan difokuskan pada citra fisik perempuan yang mewakili konstruksi masyarakat terhadap standar kecantikan perempuan yang direpresentasikan oleh tokoh Dewi Sinta dalam Serat Ramawijaya. Menurut standar kecantikan yang dikonstruksikan oleh masyarakat, idealnya kata cantik yang disandang terkhusus bagi perempuan Jawa, dicitrakan sebagai makhluk yang penuh kelembutan, kesetiaan, susila, rendah hati, pemaaf, dan penuh pengabdian (Endraswara dalam Agustijanto Indrajaja, 2017:106). Bahkan tak jarang masyarakat juga membuat standar yang jelas dengan menentukan bentuk atau karakteristik fisik perempuan, seperti tubuh yang langsing dan putih mulus, bibir penuh, wajah tirus, jari tangan lentik dan standar lainnya. Tak hanya bagi perempuan Jawa, standar kecantikan juga berlaku bagi perempuan mana saja yang terlingkup dalam lingkungan yang sempit 
akan nalar dan mengobjektivikasikan perempuan. Pemahaman tersebut lahir di tengah masyarakat patriarkis yang masih mengotak-kotakkan juga mengobjektiviasi perempuan, apalagi sampai mengatur penampilan perempuan, tak peduli itu atas campur tangan Tuhan maupun yang dikehendakinya sendiri. Citra fisik perempuan yang digambarkan melalui tokoh Dewi Sinta yang memiliki paras atau fisik yang cantik, setia, dan kepatuhan akan ketentuan Tuhan, akan dipaparkan lebih jelas dalam penjelasan di bawah ini.

\section{Tentang Dewi Sinta}

Dewi Sinta merupakan salah satu tokoh penting yang ada dalam cerita Ramayana. Dewi Sinta adalah putri sulung dari Raja Janaka, seorang raja dari kerajaan Mithila. Pada suatu ketika, Raja Janaka mengadakan sayembara untuk mendapatkan putri sulungnya yang sangat ia cintai. Tidak sembarang bentuk sayembaranya, yakni siapapun yang bisa membentangkan tali busur milik Dewa Siwa. Sayembara tersebut dimenangkan oleh Rama, dan akhirnya diputuskan menjadi pendamping hidup Dewi Sinta dan dibawa ke Ayodhya bersama Rama. Sepanjang hidupnya memang Dewi Sinta berada di bawah payungan istana, selalu diperlakukan baik dan dicukupkan segala kebutuhan dengan kemewahan. Namun, hal tersebut tidak membuat Dewi Sinta tergila-gila dengan harta dan dunia. Ia tetap rendah hati, tidak menyombongkan kedudukannya sebagai putri raja dan istri seorang Rama. Hingga suatu ketika, pada saat Rama menjalani masa pengasingan di hutan, Dewi Sinta pun tetap teguh pada pilihannya untuk mengikuti kemanapun Rama pergi, sekalipun harus meniggalkan kenikmatan dunia yang dimilikinya. Sikap setia Dewi Sinta tak lantas membuat Rama ingin terus melindunginya dan semakin besar pula rasa cintanya. Namun pada saat pengasingan itulah, banyak gangguan dating menguji mereka berdua, salah satunya adalah dengan adanya jebakan kijang kencana ulah Rahwana atau dalam Serat Ramawijaya banyak disebut dengan nama Dasamuka, yang juga mencintai Dewi Sinta dan berusaha merebutnya dari Rama. Sekalipun Dewi Sinta telah menjadi milik Rama, Dasamuka tidak mundur dan tetap selalu melihat Dewi Sinta adalah sosok yang cantik, dan tak pantas menjadi pendamping Rama. Mengenai bagaimana wujud kecantikan Dewi Sinta, berikut penyajian datanya yang mana, pencitraan Dewi Sinta tersebut diungkapkan oleh tokoh lain.

\section{Kecantikan Paras Dewi Sinta}

Dalam Serat Ramawijaya, Dewi Sinta digambarkan menjadi sosok yang cantik. Tak hanya cantik dari segi fisiknya, Dewi Sinta juga cantik budinya, dan dicitrakan sebagai simbol kecantikan perempuan. Narasi yang ditujukan kepada Dewi Sinta perihal kecantikannya dapat dibuktikan melalui beberapa kutipan data di bawah ini:

\footnotetext{
//lir barongan polahè Sang Aji/ Babo babo arèning ngong/ Dèwi Sinta tumungkul tangisèl Dasamuka ngandika aris/ Lah mênê ng ngari mami/ Dhuh Sinta wong ngayu

Terjemahan:

//Sang Aji tingkahnya seperti barongan / Aku berani menguak/ Dewi Sinta menangis sendu/ Dasamuka berkata manis/ Pada akhirnya aku ditinggal/ Duh Sinta yang cantik (Mijil bait 24)
}

Dalam kutipan tersebut, ketika kondiai Dasamuka sedang membujuk Dewi Sinta agar tidak terus-terusan menangis dengan memuji kecantikannya. Pada saat itu merupakan kejadian ketika Dewi Sinta telah ditemukan setelah menghilang. Dewi Sinta merasa ketakutan dan ingin segera pulang menemui suaminya, Rama. Namun yang didapati di sana ada Dasamuka yang terus menerus mendekati dan merayunya untuk mau pulang bersamanya. Akhirnya ada Dewi Trijatha yang menenangkan Dewi Sinta agar tetap tenang dan tak perlu bersedih. Meskipun dalam keadaan yang masih kacau, Dasamuka tak hentinya merayu dan memuji-muji kecantikan Dewi Sinta, yang 
mana menjadi bukti bahwa tokoh lain menganggap dan menilai jika Dewi Sinta adalah sosok perempuan yang cantik, seperti pada kutipan berikut.

\begin{abstract}
//Dhangah dhangah Sinta wong ngakuning/ Ddhomês luwês tur moblong/ Ingsun ratu sugih êmas kiyèl Sêngkang jamang ingsun sugih/ Kêmiriku rong pêthi/ Brambangku sak lumbung

Terjemahan:

//Sinta orang yang tinggi semampai dan berkulit langsat/ Perangainya lembut serta putih bersih/ Aku ratu yang punya banyak emas/ Jamangku tak berpenghuni/ Kemiriku dua peti/ Bawang merahku sebanyak satu lumbung (Mijil bait 25)
\end{abstract}

\title{
//Dèwi Sinta awèt tan manis/ ingsun atêtakon/ buron apa aputih rupanèl lan ing êndi omah ira iki/ sapa ingkang kêkasih/lah apa gawèmu \\ Terjemahan: \\ //Dewi Sinta awet muda dan manis/ Aku bertanya/ Buruk atau putih wajahnya/ Dan dimana rumahnya/ Siapa kekasihnya/ Apa pekerjaanmu (Mijil bait 33)
}

Pada mijil bait 25 dan 33 lebih spesifik penyebutan gambaran fisik Dewi Sinta yakni memiliki postur tubuh tinggi semampai, kulitnya putih langsat serta memiliki perangai yang lemah lembut, seperti yang diucapkan Dasamuka. Karena berniat untuk mempengaruhi Dewi Sinta dengan cara merayu berkali-kali, Dasamuka juga menawarkan beberapa kekayaannya kepada Dewi Sinta sebagai alat untuk menarik perhatiannya agar mau ikut bersama Dasamuka. Dalam praktiknya, hal tersebut merupakan bentuk dari mencari pengakuan. Dasamuka dengan segala yang dimilikinya dan menunjukkan dirinya kepada Dewi Sinta agar mau hidup bersamanya. Terlepas dari wujud fisik Dasamuka yang besar dan menyeramkan, ia memang sangat mencintai Dewi Sinta. Karena, Dewi Sinta merupakan jelmaan dari mendiang jantung hatinya yang sangat ia cintai, dan semua ada pada diri Dewi Sinta. Maka Dasamuka rela menghabiskan tenaga dan segalanya untuk mendapatkan Dewi Sinta. Praktiknya, cinta tidak ada yang dapat diperjuangkan secara cuma-cuma. Manusia seakan dibuat kikuk di hadapan cinta, bahkan kedudukan tahta, kekayaan, kekuasaan yang agung akan luluh dengan cinta, tidak ada artinya tanpa cinta. Praktik merayu Dewi Sinta yang mengobjektivitas fisiknya banyak tersurat pada serat ini. Menurut Kalis Mardiasih (2019:64) penyebab dari pengobjektivikasian perempuan ini dikarenakan terbatasnya ruang gerak perempuan. Persoalan kekuasaan, dominasi maupun penindasan dari yang kuat kepada yang lemah atau kapitalisme, memandang tubuh perempuan sebagai objek, yang mana perempuan hanya sebatas dari kata "cantik" itu sendiri.

\section{Kesetiaan Dewi Sinta Kepada Rama}

Wujud kesetiaan Dewi Sinta ditunjukkan dalam beberapa kutipan data pada Serat Ramawijaya. Rasa cinta yang tulus dan komitmen untuk menjaga perasaan, dilakukan Dewi Sinta untuk menjaga kesucian diri dan perasaannya terhadap Rama. Segala hal akan dilakukan oleh Dewi Sinta untuk tetap menjaga diri dan menjunjung kesetiaan di atas segalanya. Pemaknaan setia sebagai seorang istri, menurut Purwadi dalam Agustijanto Indrajaja (2017:110), istri yang dikatakan ideal setidaknya memiliki tiga sifat. Yang pertama yakni sawanda (serupa atau sewarna), yakni sifat mampu menyelaraskan antara keinginan lahir dan keinginan batinnya dalam hal melayani suami sama halnya seperti memperlakukan dirinya sendiri. Kedua, sifat saekapraya, yaitu sifat yang mampu menyelaraskan keinginan diri dengan keinginan suaminya. Dan yang ketiga sifat sajiwa (satu jiwa) yang berarti memiliki kesetiaan kepada lelakinya, seperti kesetiaan kepada dirinya sendiri untuk berkomitmen menjaganya. Bentuk kesetiaan Dewi Sinta tidak secara langsung dikatakan, namun secara tersirat dapat dipahami dari beberapa kutipan data dari Serat Ramawijaya, sebagai berikut. 
//kowè ngaku mondraguna sêti/ dènè nora tagon/ kaya maling dasamuka atinèl barêng gawa iya awak mami/ dèn cidra si anjing/bojoku tan wêruh

Terjemahan:

//Kau mengaku sakti mandraguna/ Tetapi tidak bisa dipercaya/ Seperti maling, Dasamuka hatinya/ Lalu membawaku/ Raden dilukai si anjing/ Suami tidak mengetahuinya (Mijil bait 27)

\begin{abstract}
//yèn wêruh bojoku sang pêkik/ iya rama disinom/pêsthi tugêl gulumu Sang rojèng/ dasamuka runtik/ dipun panah sirahmu gulinting/ dasamuka runtik/ kurda Sang prabu

Terjemahan:

//Jika diketahui oleh suamiku yang rupawan/ Rama sedang disinom/ Pasti patah lehermu Sang Agung/ Dasamuka sakit hati/ Dipanah kepalamu jatuh menggelinding/ Dasamuka sakit hati/ Amarah Sang Prabu (Mijil bait 28)
\end{abstract}

Pada dua bait tembang mijil tersebut, Dewi Sinta menunjukkan kemarahannya kepada Dasamuka. Bait 27 Dewi Sinta merasa marah dan mengumpat kepada Dasamuka bahwa ia tidak dapat dipercaya, seenaknya saja ia berkata manis dan merayu Dewi Sinta. Sama halnya pada bait 28, Dewi Sinta juga mengisyaratkan jika saja suaminya Rama mengetahui perbuatan Dasamuka yang terus menerus mengusik dan merayunya, pasti Dasamuka akan dihabisi pada saat itu juga. Dari kedua bait itu saja, Dewi Sinta selalu menegaskan kemarahannya kepada Dasamuka. Ia mencoba melindungi diri dengan menyebutkan nama dan keberanian Rama. Dengan melakukan hal tersebut, Dewi Sinta menunjukkan kesetiaannya terhadap Rama. Karena baginya, Rama adalah sosok yang kuat, yang pasti dapat melindunginya dari segala marabahaya. Hal tersebut bukan menunjukkan sikap manja dan bergantung pada suaminya saja, namun Dewi Sinta menegaskan jika ia masih punya dan masih bersama Rama suami yang dicintainya. Jadi membawa-bawa nama Rama merupakan sebuah ancaman dan peringatan bagi Dasamuka yang masih terus-menerus mengusiknya. Sebagai suami, Rama tidak tinggal diam jika istrinya diculik dan dibawa ke Alengka oleh Dasamuka atau Rahwana. Maka, ia menyuruh utusan untuk dating ke Alengka dan memastikan bagaimana kondisi Dewi Sinta.

//prabu kencana umatur ngabêkti/ riwonda awak ingong/ malih awan wisma kula anggèr/milanipun kawula mariki/ karsanya jêng gusti/ amirsa Sang ngayu

Terjemahan:

//Prabu Kencana berbicara dengan penuh hormat/ Kera itu adalah saya / Semakin siang rumah saya semakin tidak karuan/ Maka dari itu saya kemari/ Sesuai kehendak gusti (Rama)/ Menemui Sang Ayu (Dewi Sinta) (Mijil bait 34)

//inggih kula kinèngkèn marang gusti/ rama wijaya katong/malih awan kadhatonè anggêr/ mawi bala riwonda gusti/ inggih hih awak mami/ dèn utus sang prabu

Terjemahan:

//Iya saya diutus oleh gusti/ Raja Rama Wijaya/ Semakin siang keratonnya semakin tidak karuan/ Para kera membawa pasukan/ Iya ini saya/ Diutus sang prabu (Mijil bait 35)

//apan èstu gusti wontên ngrêki/ ngalèngka kang êgon/ yèn saka èstu gih kula anggêr/ ponang supè pakatur rajêng gusti/ warnanên sang dèwi/ prasêtya satuhu Terjemahan: 
//Hendak direstui oleh gusti di sini/ Bertempat di Alengka/ Sesungguhnya saya juga asal-asalan/ Yang lupa saya sampaikan kepada gusti/ Diceritakan oleh Sang Dewi/ Sanggup untuk setia (Mijil bait 36)

//gya tinampan marang sinta dèwi/ tan pangling sang sinom/yèn kalpika dyan rama kang duwè/ angandika wahu Sang dèwi/ anggagas kang pênggalih/ngandika sang ngayu

Terjemahan:

//Segera diterima oleh Dewi Sinta/ Tidak lupa apa itu sinom/ Kalau cincin Rama yang punya/ Ujar Sang Dewi tadi/ Menyampaikan apa yang dipikir/ Ucapan Sang Ayu (Mijil bait 37)

Karena kekhawatiran Rama atas kondisi Dewi Sinta, maka ia menyuruh utusan untuk mendatangi dan memastikan bagaimana kondisi Dewi Sinta di Alengka. Para kera utusan Rama mendatangi Alengka dengan membawa pasukan, berjaga-jaga bila terjadi suatu hal yang buruk. Para utusan menjelaskan kedatangannya adalah perintah dari Prabu Kencana atau Rama. Dewi Sinta senang mengetahui bahwa Rama masih mencari dan mengharapkan kabar dan kondisinya. Lalu Dewi Sinta melihat cincin yang tidak lain adalah cincin pemberian Rama suaminya. Dewi Sinta menitipkan pesan kepada utusan untuk disampaikan kepada Rama, bahwa sekalipun ia diculik dan ada bersama dengan Dasamuka, dapat dipastikan bahwa Dewi Sinta sanggup untuk setia.

Pengiriman utusan ke Alengka disebabkan adanya unsur kecemburuan yang tumbuh merupakan hal mutlak disebabkan oleh persepsi diri sendiri. Tidak akan pernah bisa untuk mengatasi atau minimal meminimalisir rasa kebencian dan kedengkian yang remeh, dan akan terjadi secara terus-menerus hal seperti menyalahkan, mengutuk bahkan memburu orang lain yang menyebabkan kecemburuan itu ada. Seperti halnya yang dilakukan Ramawijaya atau Rama terhadap Dasamuka, berusaha menghancurkannya karena Rama merasa kesal. Cemburu bisa dikatakan bawaan sejak lahir, jika tetap melanggengkan rasa tersebut dan tanpa melakukan untuk menyelidiki dan mencari sebab akibatnya. Adanya keyakinan bahwa siapapun yang mencoba memantik rasa tersebut, harus ditebus dengan kematian, maka dari itu Rama sangat bengis terhadap Dasamua. Obsesi kecemburuan terletak pada rasa ingin memiliki yang tinggi dan balas dendam. Sama halnya membenarkan bahwa kecemburuan sebagai bentuk senjata pertahanan yang untuk melindungi hak milik akan sesuatu, seperti Dewi Sinta ini.

Kesetiaan Dewi Sinta merupakan perwujudan kesucian cinta seorang istri terhadap suaminya. Sekalipun Dewi Sinta dalam keadaan terhimpit, dirayu dan digoda terus-menerus oleh Dasamuka, yang juga seorang raja di kerajaan Alengka, yang memiliki kekuasaan dan harta berlimpah, Dewi Sinta tetap teguh. Teguh atas pendirian dan hatinya untuk tetap setia dan tidak mau berbuat macam-macam selama ia tidak bersama suaminya. Karena menurut Dewi Sinta hanya Rama cinta sejatinya. Dewi Sinta menggambarkan sosok perempuan yang setia dan tunduk atas apapun perintah dan kemauan suaminya. Dalam berbagai narasi yang dijelaskan perihal pembuktian kesucian dan kesetiaan Dewi Sinta dengan cara membakar diri, namun sayangnya dalam naskah ini tidak disebutkan sekalipun. Namun dengan adanya beberapa kutipan data dari naskah dapat menjadi bukti bahwa Dewi Sinta senantiasa memegang teguh kesetiaan atas nama cintanya kepada Rama.

\section{Sikap Patuh dan Berserahnya Dewi Sinta}

Selain memilih untuk teguh dalam pendiriannya dengan menjaga kesetiaan terhadap Rama, Dewi Sinta juga memiliki sikap patuh dan berserah diri. Kedua sikap tersebut berbeda namun saling berkaitan. Patuh yang dimaksud di sini yakni patuh kepada ketentuan apapun dari Tuhan, sama halnya dengan berserah diri, menyerahkan segalanya kepada ketentuan Tuhan. Berserah diri 
bukan berarti diam, pasrah, dan menyerah atas keadaan yang terjadi, namun harus disertai segala upaya usaha sebagai pendukungnya. Dari sikap tersebut, menggambarkan bahwa Dewi Sinta adalah perempuan yang mempercayai apa yang sudah menjadi kehendak Gusti atau Tuhannya entah Bahagia, sedih, gembira, cobaan dan lainnya akan bisa dilalui dengan berdoa juga usaha. Tak pernah takut akan apa yang terjadi kedepannya dan risikonya, sekalipun tentang kematian, Dewi Sinta meyakini kematian dan tidak takut akan hal tersebut.

Sikap berserah diri yang dilakukan oleh Dewi Sinta yakni ketika dirinya dalam keadaan terhimpit oleh gangguan Dasamuka untuk hidup bersamanya. Dewi Sinta yang terus dipaksa dan dirayu dengan berbagai macam cara, namun Dewi Sinta tetap menolak. Selain membawa-bawa dan meyakini bahwa suaminya Rama yang terkasih akan menyelamatkannya, Dewi Sinta juga sering menjawab jika ia lebih baik mati saja daripada harus memupuskan rasa cinta dan merobohkan kesetiaannya daripada harus hidup bersama dengan Dasamuka menjadi pasangan hidupnya. Di bawah ini adalah kutipan datanya:

\section{//ayo nuli sun pondhong wong kuning/ wong cèthi cuwèr rimabalong/ dèwi Sinta} cumênthêng saurè/ babo aja polang rêsmi/ sun plaur mati/ yèn kasiya kêsambut Terjemahan:

//Ayo segera kubawa orang kuning/ Teman dekat perempuan itu yang berkelana (Trijatha pergi)/ Dewi Sinta menjawab demikian sama/ Dhuh, jangan mencari cahaya/ Aku lebih baik mati/ Bila sudah tertulis (Mijil bait 26)

\section{//Senadyan anoman wau kang winarnil anèng luhurè kayon/ daya pati micorèng kalbunèl nyata kukuh gustiku Sang dèwil paran polah mamil gèningsun umatur Terjemahan: \\ //Meskipun tadi Anoman yang menceritakan/ Kepada leluhurnya di pepohonan/ Daya kematian terpancar dari dalam kalbunya/ Sungguh kuat gustiku Sang Dewi/ Seperti apa tindakanku/ Biar aku yang bicara (Mijil bait 30)}

Pada kedua bait tembang mijil tersebut. membuktikan jika Dewi Sinta tidak takut untuk mati. Apalagi dalam waktu yang cukup lama, Dewi Sinta secara terus menerus dirayu dan digoda oleh Dasamuka agar mau hidup bersamanya. Namun, atas kebencian dan kerisihan Dewi Sinta atas semua rayuan Dasamuka, lebih baik ia mati daripada harus menjadi istri raksasa Dasamuka sekalipun memang Dasamuka tulus mencintai Dewi Sinta. Keyakinan dan pasrah dalam menerima takdir sekalipun itu tentang kematian, ternyata telah terlihat jelas dalam diri Dewi Sinta. Seperti yang diucapkan Anoman, yang menurutnya aura penerimaan atas beban atau kesalahan, sudah terlihat jelas bahkan terpancar dari dalam diri Dewi Sinta. Seakan ia siap akan menimpa cobaan dalam bentuk apapun, sebagai makhluk yang patuh dan berserah kepada Tuhan dan wujud kesetiaan terhadap Rama. Namun, berbeda lagi ketika kematian hendak menghampiri orang yang dipercaya Dewi Sinta. Ia akan merasa sedih dan tak berdaya jika harus ditinggal pergi, seperti kutipan di bawah ini.

//inggih kula arpêrang gusti/ perang pupuh pang telung panggon/ inggih kula duktanè Sang rojèng/ botên nistha awak mami/ inggih duktali gulih/ gusti awak ingsun

Terjemahan:

//Iya hamba mau berperang gusti/ Perang pupuh di tiga tempat/ Iya hamba utusan Sang Raja/ Hamba tidak akan direndahkan/ Baiklah hamba tidak akan kembali (sebelum menang)/ Gustiku (Mijil bait 41) 
//prabu kencana umatur ngabêkti/ idi Sang sinom/ dèwi Sang anta pan alon nuwusè/ iya bênêr olèh pratadha iku/ apan ing ngutus gusti/ iya têmah lampu

Terjemahan:

//Prabu Kencana berbicara dengan penuh/ Izin kepada Sang Sinom/Sang Dewi berujar lirih tak bersemangat/ Iya benar mendapatkan pertanda itu/ Akan disampaikan kepada gusti/ Ditakdirkan untuk mati (Mijil bait 42)

//dèwi Sang nata angandika malih/ aja sira perang tanggon/ dapati mênèk mati kowè/ sapa baya kang asung warti/marang kangmas ugi/ aja pêrang pupuh Terjemahan:

//Sang Dewi bersabda lagi/ Kau tidak dapat dipercaya jangan berangkat perang/ Nanti kau mati/ Siapa yang akan membawakan berita marabahaya/ Kepada kakak (laki-laki) juga/ Jangan perang pupuh (Mijil bait 43)

Meskipun Dewi Sinta memiliki sifat yang lemah lembut, setia, sikapnya patuh dan berserah diri, namun jika orang yang dipercaya kebaikannya akan menemui suatu marabahaya, maka ia tidak akan rela membiarkan mereka pergi. Seperti pada kutipan dua bait mijil di atas. Kedua kutipan tersebut telah menggambarkan jika Dewi Sinta didatangi oleh Anoman, kera putih utusan Rama. Dewi Sinta adalah sosok yang disegani oleh Anoman, maka ia meminta doa dan restu kepada Dewi Sinta karena hendak berangkat perang pupuh. Anoman ini sering menghampiri dan memastikan kondisi Dewi Sinta dan dilaporkan kepada Rama, begitupun sebaliknya. Namun, dikarenakan hanya melalui Anoman Dewi Sinta bisa bertukar informasi perihal situasi dan kondisi Rama, ia tak rela dan tak merestui Anoman berangkat perang pupuh. Ia berjanji tidak akan kembali jika ia belum memenangkan peperangan, jika ia menang ia akan pulang. Namun, yang didapati Dewi Sinta memiliki firasat buruk akan terjadi pada Anoman jika tetap berangkat perang. Dewi Sinta berpikiran jika Anoman akan mati ketika perang. Dan jika Anoman telah mati, takkan ada lagi sumber bertukar informasi untuk Dewi Sinta.

\section{Relevansi Tokoh Dewi Sinta dengan Kesetiaan Istri}

Setelah dijelaskan beberapa karakter tokoh Dewi Sinta sebagai perempuan yang cantik, kini dikaitkan dengan kesetiaan seorang istri. Melihat Dewi Sinta juga merupakan seorang istri yang sedang memperjuangkan kesucian dan kesetiaan cintanya, dalam kisah Serat Ramawijaya. Kini, kita kaitkan dengan kondisi seorang istri yang setia kepada suaminya. Sebelum itu, perlu diketahui bahwa kesetiaan itu memang adalah bagian dari keintiman suatu hubungan apapun, termasuk hubungan sebagai suami dan istri. Seperti pendapat Jeane Yolanda (2019:33) yang menilai bahwa kesetiaan adalah suatu hal yang penting untuk menunjang keberlangsungan hubungan dalam jangka panjang. Seperti ketaatan yang dilakukan Dewi Sinta untuk tetap teguh menjaga kesucian dirinya yang tidak mau disentuh sedikitpun oleh Dasamuka, serta segala penolakan rayuan dari Dasamuka, merupakan wujud dari kesetiaan itu sendiri.

Relevansinya dengan kesetiaan istri di sini ranahnya setia kepada suami. Yang mana, dalam budaya Jawa ada narasi bahwa suwarga nunut neraka katut yang dilabelkan kepada perempuan sebagai istri. Narasi tersebut memiliki makna bahwasannya menjadi seorang istri harus mengikuti apapun yang diucapkan juga dilakukan oleh suaminya, harus nurut. Dianalogikan surga dan neraka sebagai bentuk keabadian tempat kembali manusia atas pertanggung jawabannya hidup di dunia, namun terkesan begitu membebani dan mengikat perempuan sebagai istri. Jika suami masuk neraka misalnya, namun sang istri masuk surga berdasarkan perhitungan amal baiknya, tapi hal tersebut tidak berlaku. Karena, bagaimanapun juga istri akan katut atau ikut masuk ke neraka karena suaminya masuk neraka. Seakan perihal amalan manusia kepada Tuhannya pun, perempuan sebagai istri turut menanggung beban yang dilakukan suaminya. Jadi dalam 
pembahasan kali ini, kesetiaan merupakan hal yang wajb dan dilarang untuk dilewatkan oleh perempuan sebagai istri terhadap laki-laki yang menjadi suaminya, dalam berbagai hal.

\section{Cantik Adalah Tantangan}

Perempuan seakan memiliki tugas yang berat namun dianggap ringan oleh masyarakat yang patriarkis dan mengobjektivitas perempuan. Seakan perempuan berkutat dengan dirinya sendiri. Perempuan mengalami fenomena biologis seperti menstruasi, mengalami kehamilan dan menyusui. Bahkan sejak pertama lahir, perempuan sudah dibungkus dengan berbagai hal wajib yang harus dilakukannya agar bisa disebut "perempuan", banyak larangan dan aturan yang strict atau ketat dan menyeramkan yang harus dipatuhi perempuan, jika tidak bisa dianggap melawan dan memiliki cap bukan perempuan baik, yang mana hal tersebut hanyalah sebagai bentuk pelestarian struktur sosial yang bersifat maskulinitas.

Kemampuan yang harus dimiliki perempun di luar perannya secara biologis, juga ditekankan untuk memenuhi standar yang dibentuk oleh masyarakat sendiri. Suatu keharusan yang dilakukan perempuan antara lain menjalani peran seperti perawatan, pemberian kasih sayang, pemeliharaan, mengurusi sesuatu, baik untuk dirinya maupun orang lain. Perempuan sendiri dalam masyarakat dituntut untuk menjadi pribadi yang cantik secara fisik mulai dari warna kulit yang putih, wajah yang mulus dengan hidung mancung, perawakan tinggi dengan kaki jenjang dan badan langsing. Tak cukup dari fisik saja namun juga dengan kepribadiannya yang turut diatur oleh kondisi sosial masyarakat. Dianggap menjadi perempuan yang baik sesuai dengan standar masyarakat yakni mereka yang memiliki sifat lemah lembut, keibuan, halus tutur katanya, penuh kasih dan sayang perilakunya, mudah menangis dan tersinggung adalah suatu kewajaran yang dilambangkan sebagai sifat wajib perempuan, yang mana perempuan diminta untuk berada pada statement tersebut guna mewujudkan serta melanggengkan wujud dari standar buatan masyarakat sendiri.

Apalagi jika perannya sudah menjadi seorang istri, bukan menjadi suatu pembaruan bagi energi dan semangat untuk berkarya, yang ada menjadi beban jika perempuan tumbuh di tengah masyarakat yang patriarkis. Selain harus memenuhi standar kecantikan sebagai perempuan, juga memenuhi ekspektasi masyarakat untuk menjadi istri yang ideal. Seakan tidak akan ada habisnya jika terus-menerus menghiraukan narasi-narasi masyarakat yang membuat standar tertentu bagi tubuh dan kehidupan perempuan. Betapa menyiksa dan menderitanya perempuan harus terkurung dalam stigma dan harus memenuhi kriteria buatan masyarakat. Jika tidak, masyarakat bahkan lingkungan terdekat atau keluarga dengan mudahnya menentukan dosa dan kesalahan perempuan juga memberikan penilaian yang kurang baik dalam kehidupan bermasyarakat. Maka dari itu, sebagai perempuan harus menyadari jika mendapati lingkungannya tidak sehat seperti itu. Yang harus dilakukan bukanlah patuh dan berusaha memenuhi ekspektasi masyarakat patriarkis, namun harus melawan untuk kebebasan sebagai individu yang memiliki hak dan kewajiban yang merdeka.

\section{Perempuan Patuh}

Menjadi perempuan yang patuh kepada suami juga tata aturan masyarakat yang patriarkis merupakan sesuatu yang berat untuk dilakukan oleh seorang istri. Selama hidup berumah tangga, perempuan sebagai istri harus tunduk dan patuh pada suami. Memang hal tersebut harus dilakukan sebagaimana istri mematuhi dan menghormati suami sebagai imamnya. Namun, hal tersebut tidak lagi berlaku jika suami, lingkup keluarga yang tidak mendukung kebebasan dalam berekspresi. Apalagi sampai membimbing dan menjerumuskan pada hal yang kurang baik. Malangnya, sebagai seorang istri, entah itu baik atau buruk, menguntungkan atau merugikan, membangun atau menjatuhkan, wajib bagi istri untuk mematuhinya jika itu keluar dari mulut suaminya. Ketika istri mencoba meluruskan maksud yang tidak sepatutnya, dianggap melawan dan durhaka kepada suaminya. Misal saja pada kasus seorang istri yang diajak bekerjasama dengan suaminya untuk 
mencari nafkah. Memang niatnya baik, namun lihat dahulu pekerjaan apa yang dilakukan. Jika pekerjaan yang dilakukan adalah saling bekerjasama untuk mencuri, maka sebagai istri seharusnya meluruskan niat buruk suaminya. Bukan malah tunduk dan takut akan dosa. Sebagai istri memang diharuskan untuk patuh, namun harus melihat kembali apa yang dipatuhi, diikuti dan dilakukan.

\section{Sulit Mengembangkan Potensi Diri}

Ini merupakan salah satu ketakutan yang muncul ketika perempuan hendak memilih untuk menjadi seorang istri. Ia akan merasa kesulitan untuk mengembangkan diri sesuai dengan potensinya. Perempuan jika sudah menjadi istri, dianggap cukup berperan aktif dan mengabdi penuh dalam pekerjaan domestik di rumah. Hal tersebut bisa saja terjadi di tengah lingkungan keluarga atau msayarakat yang mengalami ketimpangan perihal gender. Perlu adanya penyetaraan gender yang mana menyamakan kesempatan, kedudukan, hak dan partisipasi sebagai manusia seutuhnya, tanpa harus dibatasi oleh gender. Dalam hal kesetaraan bahwa kesetaraan adalah konsep yang menegaskan bahwa laki-laki juga perempuan memiliki dan berada pada kondisi, perlakuan serta kesempatan yang tidak berbeda dalam mewujudkan apa saja yang menjadi potensi diri. Tak hanya itu, kesetaraan juga mencakup beberapa aspek dalam pembangunan juga masyarakat seperti aspek ekonomi, sosial, budaya serta politik.

Namun kesulitan dalam pengembangan diri seorang perempuan yang telah menjadi istri, masih menghantui. Dalam semua aspek kehidupannya jika telah menjadi seorang istri, semua berada di bawah kontrol sang suami. Maka dari itu, sebagai istri harus patuh dan siap melayani sepenuhnya apa yang menjadi kebutuhan suami. Beban yang dipikul juga semakin besar ketika perempuan dijadikan indeks atau penentuan dosa manusia (Anthony Synnott dalam Eti Nurhayati, 2018:15). Hal tersebut telah menjadi narasi yang toxic bagi perempuan. Karena, seakan segala gerak-gerik perbuatan perempuan mengandung dosa dan harus siap menanggung dosa suami juga keluarganya. Semakin nyata jika kehidupan perempuan menjadi sempit dan tidak bisa utuh, berdikari dan otonom. Selalu ada standar, batasan, dan larangan baik dari sisi fisik, tingkah laku sampai ucapannya. Perempuan kesulitan dalam memenuhi hak dan memeroleh kewajiban sebagaimana menjadi manusia seutuhnya.

Penyebab dari adanya narasi bahwa perempuan harus memiliki fisik dan kepribadian feminin dalam pandangan masyarakat patriarkis ini adalah adanya ketakutan atas kekalahan yang nantinya akan dialami oleh laki-laki patriarkis jika perempuan memiliki power untuk maju dan berkembang melebihi laki-laki. Menganggap perempuan sebagai opsi kedua yang tidak memiliki otoritas dan ruang untuk menyuarakan dan bergerak kecuali dalam ruangnya sendiri sebagai perempuan yang menyeramkannya lagi adalah ruang ciptaan masyarakat patriarkis sendiri. Menganggap perempuan sebagai objektivitas semata yang tidak memiliki nilai lebih dari itu.

Perempuan seringkali dijadikan opsi komplementer, dijadikan pilihan sekunder bahkan tidak dibutuhkan. Hal tersebut bisa terjadi karena masih tumbuh subur stereotype gender di tengah masyarakat modern yang menganggap bahwa laki-lakilah main power dalam segala bidang. Lakilakilah yang vokal untuk menyuarakan apapun yang mereka mau. Laki-lakilah yang menjadi poros utama dalam lini kehidupan. Perempuan disembunyikan dibalik ketiak patriarki. Beruntung masih memiliki peranan di bidang domestik, menurut mereka yang menjunjung nilai patriarki. Padahal seharusnya laki-laki atau perempuan memiliki porsi yang sama. Tidak ada perbedaan untuk pemenuhan hak dan kewajiban. Setara dan sederajat sebagaimana manusia dihadapan Allah swt sebagai ciptaanNya. Timbul pertanyaan mendasar namun begitu mengakar di tengah stereotip masyarakat. Perempuan selalu disalahkan, mengapa tak diberi kesempatan untuk mengutarakan apa yang ingin dibicarakan berdasar apa yang ada di kepala dan hatinya di ruang publik, mengapa perempuan harus rela menjadi pihak yang mengalah, ikhlas dan sabar diperlakukan dengan tidak adil bahkan tidak boleh menentang apalagi melawan atas penindasan tersebut. 


\section{SIMPULAN}

Penggambaran tokoh Dewi Sinta dalam Serat Ramawijaya dapat mewakili bagaimana bentuk standarisasi kecantikan perempuan yang mengobjektivikasi perempuan. Menyesuaikan dengan standar masyarakat patriarkis. Sekaligus Dewi Sinta memberikan citra sebagai istri yang setia. Kesetiaan dan kesucian cinta Dewi Sinta tak membuat Dasamuka mundur dan jera terhadap penolakan Dewi Sinta. Namun Dewi Sinta tetap teguh dan tidak terkecoh atas semua kebaikan dan bujuk rayu Dasamuka. Hal tersebut juga mencerminkan bahwasannya perempuan sekalipun telah menikah tidak menjamin akan aman dari berbagai godaan.

Pemaknaan setia yang semestinya yakni perempuan sebagai istri harus bisa menjaga komitmen terhadap suaminya. Namun harus melihat konteksnya terlebih dahulu. Jika itu baik untuk kedua pihak, maka sebaiknya juga dijaga komitmennya berdua. Setia merupakan wujud ketulusan cinta yang sejati. Mencintai dalam ketulusan akan membawa kebaikan di dalam suatu hubungan, terutama dalam lingkup keluarga. Penyebab dari adanya standarisasai kecantikan perempuan yang juga berada dalam ruang lingkup masyarakat patriarkis, membuat ruang gerak perempuan semakin sempit. Tak hanya menjadi semakin terbebani dengan segala standar dalam semua aspek kehidupan perempuan, tapi juga memengaruhi ruang gerak perempuan untuk mengembangkan potensi diri yang dimilikinya.

\section{DAFTAR PUSTAKA}

Anggito, Albi dan Johan Setiawan. (2018). Metodologi Penelitian Kualitatif. Sukabumi: CV Jejak. Goldman, Emma. (2020). Suara Anarkis Pendidikan Anak, Pernikahan, dan Tragedi Emansipasi Perempuan. Sleman: Odise Publishing

Harjito. (2014). Perempuan Jawa: Antara Kesetiaan dan Kematian. Makalah dipresentasikan dalam Prosding Musyawarah dan Seminar Nasional, Surakarta. Diunduh dari http://eprints.upgris.ac.id/25/1/33perempuan\%20jawa\%20kesetiaan.pdf

Hermawan, Iwan. 2019. Metodologi Penelitian Pendidikan Kuantitatif, Kualitatif dan Mixed Methode. Kuningan: Hidayatul Quran Kuningan.

Indradjaja, Agustijanto. (2017). Penggambaran Ideal Perempuan Jawa Pada Masa Hindu-Buddha: Refleksi Pada Arca-Arca Perempuan. Jurnal Penelitian dan Pengembangan Arkeologi Vol. 6(2) November 2017 Jakarta Selatan

Juanda dan Aziz. (2018). Penyingkapan Citra Perempuan Cerpen Media Indonesia: Kajian Feminisme Jurnal Lingua Vol. 15, No. 2 September 2018, Makassar. Diunduh dari : https://lingua.soloclcs.org/index.php/lingua/article/download/478/412

Julian, R. (2016). Mitos Kecantikan Dalam Cerpen-Cerpen Dwi Ratih Ramadhany. Jurnal Poetika Vol. IV (1) 52-60 Diunduh dari: https://core.ac.uk/download/pdf/291663921.pdf

Maghfiroh, Nur Vitarini. (2018). Citra Perempuan Jawa dalam Novel Canting Karya Arswendo Atmowiloto dan Amba Karya Amba Laksmi Pamunyjak. Jurnal Estetik Vol.1 No 1 7084Diunduh dari: https://core.ac.uk/download/pdf/230671701.pdf

Mardiasih, Kalis. Muslimah yang Diperdebatkan. Yogyakarta: Buku Mojo

Nurhayati, Eti. (2018). Psikologi Perempuan dalam Berbagai Perspektif. Yogyakarta: Pustaka Belajar.

Pundarie, Nik Hita. (2017). Keutamaan Wanita Dalam Uttara Kanda (Perspektif Teologi Hindu). Jurnal Vol. 1 no. 2 Oktober 2017 Institut Hindu Dharma Negeri Denpasar, Denpasar diunduh dari https://docplayer.info/61908332-Keutamaan-wanita-dalam-uttara-kandaperspektif-teologi-hindu-oleh-nik-hita-pundarie-institut-dharma-negeri-denpasar.html

Purnomo, S. Bambang. (2013). Filologi dan Studi Sastra Lama. Surabaya: Penerbit Bintang Surabaya

Suandiani, Dewa Putu. (2016). Kajian Nilai Pendidikan Tentang Kesetiaan Seorang Istri Terhadap $\begin{array}{llll}\text { Suami } & \text { Dalam } & \text { Ramayana } & \text { Diunduh }\end{array}$ http://www.ojs.stahdnj.ac.id/index.php/pasupati/article/download/5/5 
Sukisman, JM dan Lusia. (2021). Perlawanan Stigma Warna Kulit terhadap Standar Kecantikan Perempuan Melalui Iklan. Jurnal Vol. 5 No. 1, Maret 2021 67-75. Diunduh dari http://journal.untar.ac.id/index.php/koneksi/article/viewFile/10150/6955

Sukoyo, Joko. (2015). Nilai-Nilai Moral Yang Terkandung Dalam Cerita Ramayana. Makalah dipresentasikan dalam Prosding Seminar Nasional Pembelajaran Bahasa Daerah Abad 21, Purworejo.

Diunduh dari: http://eproceedings.umpwr.ac.id/index.php/seminarpbsj/article/viewFile/155/146\#page=2 $\underline{4}$

Solanas, Valerie. Manifesto Perlawanan Perempuan. Yogyakarta: Fiscuspublishing

Yolanda, Jeane. (2019). Membedah Mitos Kesetiaan Budaya Jawa dalam Relief Wiracarita Ramayana (Studi Semiotika Roland Barthes pada Candi Prambanan Daerah Istimewa Yogyakarta). Sarjana thesis, Universitas Brawijaya. http://repository.ub.ac.id/174815/1/Jeane\%20Yolanda.pdf

Zahid, Indirawati. (2018). Definisi kata cantik: Analisis kolokasi. Issues in Language Studies, Vol. 7 No. 1-2018. Diunduh dari http://unipub.unimas.my/ojs/index.php/ILS/article/view/1615 Vol. 7 No. 1 12-36 